\title{
Distribution of Estrogen and Progesterone Receptors in Ovary of Pregnant and Non-Pregnant Sunda Porcupines \\ Teguh Budipitojo $^{1 *}$, Ermawati Dwi Yuliastri ${ }^{1}$, Dian Bekti Hadi Masithoh ${ }^{2}$, Irma Padeta ${ }^{1}$, Yosua Kristian Adi ${ }^{3}$
}

${ }^{1}$ Department of Anatomy, Faculty of Veterinary Medicine, Universitas Gadjah Mada, Yogyakarta, Indonesia

${ }^{2}$ Doctoral students of Veterinary Science, Faculty of Veterinary Medicine, Universitas Gadjah Mada, Yogyakarta, Indonesia

${ }^{3}$ Department of Reproduction and Obstetric, Faculty of Veterinary Medicine, Universitas Gadjah Mada, Yogyakarta, Indonesia

DOI: $10.36347 /$ sjavs.2020.v07i01.003

| Received: 04.01.2020 | Accepted: 19.01.2020 | Published: 30.01.2020

*Corresponding author: Teguh Budipitojo

\section{Abstract}

The population of Sunda porcupine (Hystrix javanica) is tends to decrease year by year, since it's become rarely found in nature. This study was conducted to determine the histological structure and distribution of estrogen and progesterone receptors in the ovary of pregnant and non-pregnant Sunda porcupine. Five ovaries of pregnant and nonpregnant Sunda porcupine were used as samples. The ovaries were fixed in Bouin's solution, processed with paraffin method, and cut into $5 \mu \mathrm{m}$ thickness. The tissue slides were dyed using immunohistochemical staining method to determine the distribution of estrogen and progesterone receptors. The results were analyzed descriptively. Immunoreactivities of estrogen and progesterone receptors in the ovaries of non-pregnant Sunda porcupines were detected in the atretic follicle cells and theca internal cells of developing follicle, whereas in the ovaries of pregnant Sunda porcupine, immunoreactivities of estrogen and progesterone receptors only found in atretic follicle cells. Luteal cells of corpus luteum appeared to be immunoreactive against progesterone receptor antibodies with weak intensity in the ovary of pregnant Sunda porcupine. This study was confirming that there was little difference in expression of estrogen and progesterone receptors in ovaries of non-pregnant and pregnant Sunda porcupine.

Keywords: estrogen receptor, progesterone receptor, immunohistochemistry, ovary, Sunda porcupine.

Copyright @ 2020: This is an open-access article distributed under the terms of the Creative Commons Attribution license which permits unrestricted use, distribution, and reproduction in any medium for non-commercial use (NonCommercial, or CC-BY-NC) provided the original author and source are credited.

\section{INTRODUCTION}

Sunda porcupine in which included to the family of Hystricidae in the Rodentia order has the Latin name Hystrix javanica [1]. Sunda porcupine has a unique thorn-like hair structure which is a modification of the special hair that covered the upper part of the body and serves as a self-protection. While on the bottom part of the body is covered by short black rough hair [2]. In Indonesia, this species is distributed in Java, Madura, Bali, Lombok, Sumbawa, Flores, and Tanah Djampea [3]. According to Banfield, Sunda porcupine is herbivore with monogastric type [2]. Porcupine in the Hystrix genus usually digs the soil to find their food, such as roots and tubers. The bark of the tree during the dry season, agricultural crops such as potatoes, cantaloupe and maize are also their natural feed [4]. Porcupine can give birth 1-2 times a year with litter size varying from one to three, either, twins or triplets in captivity [5].
In the reproductive system, hormone receptors are play an important role to control many mechanisms in the reproductive organ activity, such as pregnancy and estrous cycle [6]. Receptor is protein molecule that binds a signal molecule from the outside of the cell, such as neurotransmitter, hormone, antigen, or other substance. Receptors for steroid hormones are located in the plasma membrane and used second messenger to deliver signals in responsive cells [7]. Estrogen plays an important role in the reproductive system, bone homeostasis, cardiovascular remodeling and function of brain [8-10]. Estrogen receptor is a member of the steroid receptor superfamily and plays as estrogen binding so that it is able to effect [11], especially in the estrous cycle. Progesterone receptor is a ligand that binds progesterone hormone and will undergo conformational changes after binds to hormone that leads to nuclear translocation, dimerization and DNA binding $[12,13]$. 
Documentation about reproductive hormone receptors distribution in the ovarian of pregnant and non-pregnant Sunda porcupine is important as basic information. Determination of reproductive hormone receptor distribution can be used to predict the function of this hormone in the target organs. This principal data is essential to understanding the hormonal mechanism of reproductive system that can support the conservation effort of Sunda porcupine in the future.

However, study about distribution of estrogen and progesterone receptors in the ovarian of pregnant and non-pregnant Sunda porcupine (Hystrix javanica) has never reported before. This study was conducted to determine the distribution of estrogen and progesterone receptors in the ovarian of pregnant and non-pregnant Sunda porcupine with Immunohistochemical Staining method.

\section{MATERIAL AND METHOD \\ Ethical Approval}

All the method and material used in this study has been approved by the Ethics Committee for Preclinical Research of Universitas Gadjah Mada, Indonesia with No.326/KEC-PPT/IX/2015.

\section{Sample}

The organ samples were obtained from merchant in Ngawi district. Five female Sunda porcupines were sacrificed in this research. Deep anesthesia by cetanes (ketamin HCL, 10-15 mg Kg-1, IM) and rompun (xylazine HCL, $0.10-0.15$ mg Kg-1 IM) was done before opening the body cavity and decapitation of the animals. Four ovaries of nonpregnant female porcupines and one ovary of pregnant female porcupine were removed and be used as sample.

\section{Tissue Processing}

The samples were fixed in Bouin's solution for 24 hours before moved in the preservation solution, alcohol $70 \%$ solution. The ovaries were processed by paraffin method. The first step of tissue processing was dehydration process using series of alcohol solution begin from $70 \%$ alcohol for 10-12 hours, $80 \%$ alcohol for 10-12 hours, 90\% alcohol for 9-12 hours, 95\% alcohol for 8-12 hours, $100 \%$ alcohol for 4-6 hours, absolute alcohol I for 2-3 hours, and alcohol absolute IIIII for 1-2 hours respectively. Next step was clearing process using xylene solution I, II and III for 30 minutes respectively. Then, the ovarian tissues were inserted in liquid paraffin in an incubator with a temperature of $60^{\circ} \mathrm{C}$. The paraffin infiltration process was carried out in liquid paraffin I, II, and III for one hour respectively. The tissues then placed into liquid paraffin in a pot and left until the paraffin hardens. The tissue paraffin blocks were cut with microtome in $5 \mu \mathrm{m}$ thickness.

\section{Immunohistochemical Staining}

Primary antibodies used in the immunohistochemical staining were rabbit polyclonal antibody anti estradiol receptor $\alpha$ (bs-0122R, Bioss Antibodies) with 1:100 antibody dilution and rabbit polyclonal antibody anti progesterone receptor (bs0111R, Bioss Antibodies) with 1: 100 antibody dilution. Starr Trek Universal HRP Detection System ${ }^{\circledR}$ (901STUHRP700-071017, Biocare Medical, USA) was used to visualize the immunoreactivities. Immunohistochemical staining begins with deparaffinization of tissue slides using xylene I, II, and III for three minutes respectively. The rehydration was performed with absolute alcohols I, II and III, 95\%, $90 \%, 80 \%$, and $70 \%$ alcohols for three minutes respectively. Endogenous peroxidase was blocked by incubate the slides in $3 \% \mathrm{H}_{2} \mathrm{O}_{2}$ solution in methanol for 20-30 minutes. Non-specific reactions were blocked by incubating the tissue using Background Sniper for 2030 minutes. Then, the slides were incubated with primary antibodies, overnight at $4^{\circ} \mathrm{C}$ temperature. After the slides were washed with BPS solution, Trekkie Universal Link as secondary antibodies were added and the incubation were done for 20-30 minutes, followed by incubation with Trek Avidin-HRP for 20 until 30 minutes. The visualization was done by incubated the slide in the mixed substrate and diaminobenzidine (DAB) chromogen. Counterstain was done using Harris' Hematoxylin solution for 1 minute. The next step was dehydration process using alcohol solution with concentration $70 \%, 80 \%, 90 \%, 95 \%, 100 \%$, absolute alcohols I, II, and III for 1 minute respectively, continued with clearing using xylene I, II, and III for five minutes respectively. The last step was mounting the tissue slide with deck glass and Entellan ${ }^{\circledR}$ (Cat. No. 107960, Sigma-Aldrich).

\section{Analysis}

The tissue slides were examined with light microscope (NIKON YS100). The microphotographs were taken by digital camera $\left(\right.$ Optilab $\left.^{\circledR}\right)$ integrated with microscope. The results were analyzed descriptively by looking at the immunoreactive area of ovary tissue to determine the distribution of estrogen and progesterone hormone receptors in pregnant and non-pregnant Sunda porcupine ovarian.

\section{RESULT AND DISCUSSION Estrogen receptors}

Immunohistochemical staining results showed an overview of the distribution of estrogen hormone receptors in ovarian organ of pregnant and nonpregnant Sunda porcupines. Immunoreactivities of estrogen hormone receptors in ovaries of non-pregnant Sunda porcupines were distributed in the atretic follicle cells (Fig.1.B) and theca internal cells of developed follicle (Fig.1.C). However, in ovary of pregnant female Sunda porcupine, immunoreactivities of estrogen receptor distributed only in atretic follicle cells (Fig.1.A). Corpus luteum appeared non- 
immunoreactive against estrogen receptor antibodies. Immunoreactivities of estrogen receptors in the atretic follicle were appeared in the border between the degenerated tissue and other normal ovarian stromal tissues. In the theca internal of developed follicle, immunoreactive areas were visible on the cytoplasm of theca cells. Immunoreactivity of estrogen receptors was not observed in interstitial gland cells and germinal epithelial cells.
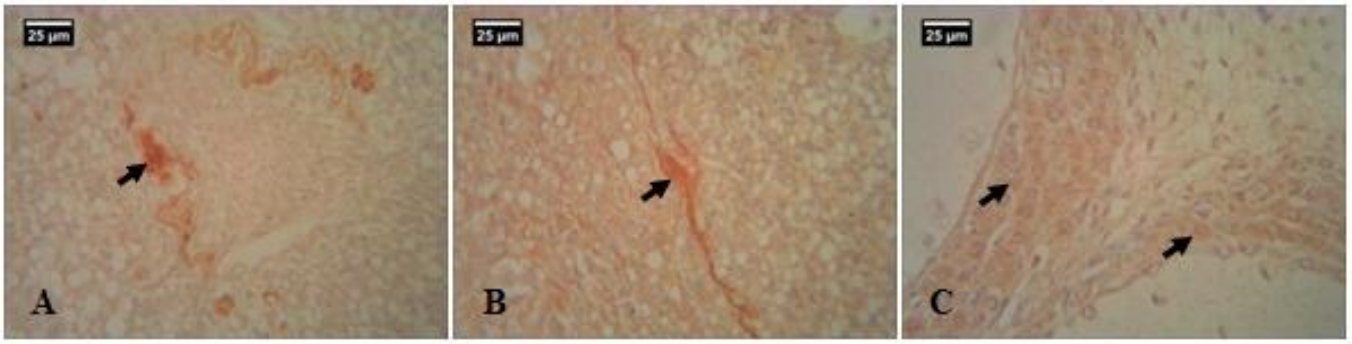

Fig-1: Distribution of Estrogen Receptors in the Ovary of Sunda porcupines (Hystrix javanica). The immunoreactive area was characterized by a strong brown color (arrow). Estrogen receptors immunoreactivities of pregnant Sunda porcupine ovary were showed in the atretic follicle cells only (A). While, estrogen receptors immunoreactivities of non-pregnant Sunda porcupine ovary were showed in the atretic follicle cells (B) and theca internal cells (C) of developed follicle

This was different from previous studies in mice that had been done by Sar and Welsch [14]. They reported that estrogen receptor $\alpha$ was localized in theca cells, interstitial gland cells and germinal epithelial cells of mice ovarian. Theca internal cells of developed follicle showed immunoreactive against estrogen receptors antibody in this research. Rissman et al. [11] reported that estrogen receptor $\alpha$ was required for negative feedback of gonad steroid on LH. This may lead to an answer why estrogen receptor $\alpha$ were detected on theca internal cells of developed follicles in the ovary of non-pregnant Sunda porcupine in this study. In this research, immunoreactivities of the atretic follicles cells appeared in the border area between the degenerated tissue and the ovarian stromal both, in the ovary of non-pregnant and pregnant Sunda porcupine. The theca of follicle was the last degenerated part of the atretic follicle [15]. It can be assumed that the immunoreactive cells were the part of theca follicle that undergoes an atretic process. Estrogen receptors bind the hormones so that can perform its function physiologically [16].

\section{Progesterone receptor}

Immunoreactivities of progesterone receptor in the ovary of pregnant female Sunda porcupine were distributed in the atretic follicle cells (Fig.2.A) and corpus luteum (Fig.2.B). Immunoreactivities of progesterone receptor in non-pregnant female Sunda porcupine ovary were distributed in the atretic follicle cells (Fig.2.C) and theca internal cells (Fig.2.D) of developed follicle. Part of the atretic follicle that appeared to be immunoreactive was the border area between the degenerated tissue and normal ovarian stromal tissue, in both, pregnant and non-pregnant Sunda porcupine ovary. The immunoreactivities of progesterone receptor antibodies in the theca internal cells were detected in the cell cytoplasm. The lutein cell of the corpus luteum in pregnant Sunda porcupine ovary also appeared to be immunoreactive against progesterone receptor antibodies.

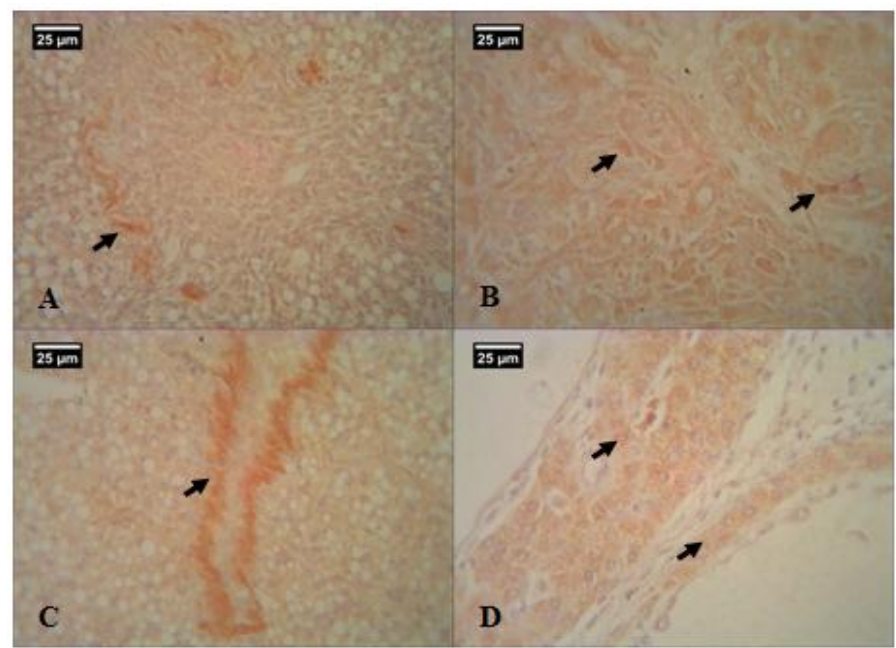

Fig-2: Distribution of Progesterone Receptors in the Ovary of Sunda porcupines (Hystrix javanica). The immunoreactive area was characterized by a strong brown color (arrow). Progesterone receptors immunoreactivities of pregnant Sunda porcupine ovary were showed in the atretic follicle cells (A) and corpus luteum (B). While, Progesterone receptors immunoreactivities of non-pregnant Sunda porcupine ovary were showed in the atretic follicle cells $(C)$ and theca internal cells $(D)$ of developed follicle. 
In mammals, progesterone has a role in the function of reproductive and follicular development $[17,18]$. Immunoreactivities of progesterone receptor in pregnant female Sunda porcupine ovary was detected in the corpus luteum and atretic follicles, while the immunoreactivities of progesterone receptor in nonpregnant Sunda porcupine ovary was detected in the theca internal cells of developed and atretic follicles. The results of this study were different from the research that has been reported by Peluso et al. [19] in which progesterone receptor proteins were detected in granulosa cells, oocytes and corpus luteum in nonpregnant mice [20]. Ovary-derived progesterone had an autocrine regulation of ovarian function. This was indicated by the present of progesterone receptors in granulosa cells after stimulation of LH in preovulatory follicles. Progesterone receptors also contributed in follicular rupture leading to ovulation [21]. In the atretic follicle, immunoreactive site appear on the boundary between the ovarian stroma and the degenerated atretic follicle. This may be due to the antral follicular atretic process. In which, the theca was the last degenerated part of atretic process [15].

\section{CONCLUSIONS}

Estrogen hormone receptors distribution were in the theca internal cells of developed follicle and atretic follicle cells in non-pregnant female Sunda porcupine ovary. Whereas, in the ovaries the pregnant female Sunda porcupine, estrogen receptors appeared only in the atretic follicle cells. The progesterone hormone receptor in the ovary of non-pregnant female Sunda porcupines appeared in the atretic follicle cells and theca internal cells of developed follicle. While, in the pregnant Sunda porcupine ovaries, progesterone receptors distribution was in the corpus luteum and atretic follicle cells.

\section{ACKNOWLEDGEMENT}

The authors are most grateful to Directorate General of Higher Education (DIKTI), Ministry of Research, Technology and Higher Education of Indonesia, with contract number: 38/LPPMUGM/2015

\section{REFERENCES}

1. Aplin K. Hystrix javanica. The IUCN Red List of Threatened Species 2016. Available from http://dx.doi.org/10.2305/IUCN.UK.20162.RLTS.T 10752A22231749.en.

2. Farida WR, Ridwan R. Giving of Formulated Pellet on Javan Porcupine (Hystrix javanica F. Cuvier, 1823): Effects on Feed Intake, Feed Conversion, and Digestibility in Pre-Domestication Condition. Jurnal Biologi Indonesia. 2011; 7(1):157-170.

3. Van Weers DJ. Notes on Southeast Asian Porcupines (Hystricidae, Rodentia). IV. On the taxonomy of the subgenus Acanthion F. Cuvier, 1823 with notes on the other taxa of the family. Beaufortia. 1979; 29(356): 215-272. ISSN 0067-
4745

4. Roze U. Porcupines The Animal Answer Guide. The Johns Hopkins University Press, Baltimore. 1997.

5. van Aarde RJ. Reproduction in captive female Cape porcupines (Hystrix africaeaustralis). Journal of Reproduction and Infertility. 1985; 75(2):57782.

6. Hewitt SC, Winuthayanon W, Korach KS. What's New in Estrogen Receptor Action in the Female Reproductive Tract. Journal of Molecular Endocrinology. 2016; 56(2):55-71.

7. Jensen EV. Steroid Hormone Receptors. In: Seifert G. (eds) Cell Receptors. Current Topics in Pathology. 1991;83.

8. Hua H, Zhang H, Kong Q, Jiang Y. Mechanisms for estrogen receptor expression in human cancer. Experimental Hematology and Oncology. 2018; 7:24.

9. Rumi MAK, Singh P, Roby KF, Zhao X, Iqbal K, Ratri A, Lei T, Cui W, Borosha S, Dhakal P, Kubota K, Chakraborty D Vivian JL, Wolfe MF, Soares JM. Defining the Role of Estrogen Receptor $b$ in the Regulation of Female Fertility. Endocrinology. 2017; 158(7):2330-2343.

10. Cooke PS, Nanjappa XMK, Ko C, Prins GS, Hess RA. Estrogens In Male Physiology. Physiological Reviews. 2017; 97:995-1043.

11. Rissman EF, Wersinger S R, Taylor JA, Lubahn DB. Estrogen Receptor Function as Revealed by Knockout Studies: Neuroendocrine and Behavioral Aspects. Hormones and Behavior. 1997; 31:232243.

12. Beato M, Herrlich P, Schütz G. Steroid hormone receptors: Many Actors in search of a plot. Cell. 1995; 83(6):851-857.

13. Gong H, Chen Y, Xu J, Xie X, Yu D, Yang B, Kuang H. The regulation of ovary and conceptus on the uterine natural killer cells during early pregnancy. Reproductive Biology and Endocrinology. 2017; 15:73.

14. Sar M, Welsch F. Differential Expression of Estrogen Receptor Beta and Estrogen Receptor Alpha in the Rat Ovary. Endocrinology. 1997; 140(2):963-971.

15. Young JM, McNeilly A S. Theca: The forgotten cell of the ovarian follicle. Reproduction. 2010; 140(4):489-504.

16. Drummond A E, Baillie A J, Findlay J K. Ovarian estrogen receptor alpha and beta mRNA expression: impact of development and estrogen. Molecular and Cellular Endocrinology. 1999; 149(1-2).

17. Abd-Elkareem $M$ and Abou-Elhamd AS. Immunohistochemical localization of progesterone receptors alpha (PRA) in ovary of the pseudopregnant rabbit. Animal Reproduction. 2019; 16(2):302-310.

18. González-Orozco JC, Camacho-Arroyo I. Progesterone Actions During Central Nervous 
System Development. Frontiers in Neuroscience. 2019; 13:503.

19. Peluso JJ, Pappalardo A, Losel R, Wehling M. Progesterone Membrane Receptor Component 1 Expression in the Immature Rat Ovary and Its Role in Mediating Progesterone's Antiapoptotic Action. Endocrinology. 2006; 147(6):3133-3140.

20. Dauda Y, Nicholas AO, Gideon DM. Effects of dexamethasone on progesterone and estrogen profiles and uterine progesterone receptor localization during pregnancy in Sahel goat in Semi-Arid region. Journal of Animal Science and Technology. 2017; 59:12.

21. Conneely OM, Mulac-Jericevic B, Lydon JP, De Mayo FJ. Reproductive functions of the progesterone receptor isoforms: Lessons from knock-out mice. Molecular and Cellular Endocrinology. 2001; 179(1-2):97-103. 